\title{
Belgeo
}

Revue belge de géographie

\section{The geography of migratory movements in Europe from the Sixties to the present day}

Géographie des mouvements migratoires en Europe des années 60 à aujourd'hui

Christian Vandermotten, Gilles Van Hamme and Pablo Medina Lockhart

\section{Q OpenEdition}

1 Journals

\section{Electronic version}

URL: http://journals.openedition.org/belgeo/12401

DOI: 10.4000/belgeo. 12401

ISSN: 2294-9135

Publisher:

National Committee of Geography of Belgium, Société Royale Belge de Géographie

\section{Printed version}

Date of publication: 30 June 2005

Number of pages: 19-34

ISSN: 1377-2368

\section{Electronic reference}

Christian Vandermotten, Gilles Van Hamme and Pablo Medina Lockhart, "The geography of migratory movements in Europe from the Sixties to the present day", Belgeo [Online], 1-2 | 2005, Online since 27 October 2013, connection on 05 February 2021. URL: http://journals.openedition.org/belgeo/12401 ; DOI: https://doi.org/10.4000/belgeo.12401

This text was automatically generated on 5 February 2021.

Belgeo est mis à disposition selon les termes de la licence Creative Commons Attribution 4.0 International. 


\section{The geography of migratory movements in Europe from the Sixties to the present day}

Géographie des mouvements migratoires en Europe des années 60 à aujourd'hui

Christian Vandermotten, Gilles Van Hamme and Pablo Medina Lockhart

\section{AUTHOR'S NOTE}

This paper is based on some of the conclusions of the research conducted within the framework of two European projects: MIRE (Migration Research in Europe, Research VS/2001/0247, GD Employment and Social Affairs) and ESPON 1.1.4. (GD Regional Politics).

\section{Introduction}

1 This paper examines the evolution of the regional migratory balances in Europe from the Sixties. It aims to show the reinforcement of the mobility in Europe during the Nineties and the growing complexity of the migratory pattern, by comparison to the prevailing one during the Sixties and the beginning of the Seventies. It is based upon an exhaustive use of the population statistics at the NUTS 2 or 3 regional levels according to the country, including Central-Eastern Europe ${ }^{1}$. The migratory balances are obtained indirectly by subtracting the total population movements and the natural movement, as good direct migratory statistics through Europe are yet missing. They are also examined according to main age groups, taking into account deaths by five-year age groups. This examination gave us the possibility to attempt to establish a typology of the European regions regarding mobility behaviours. It is evident that similar balances can conceal quite different mobility types, whose components we aimed to study with the help of the available data. The existing matrixes of interregional, or even 
international flows, were examined in order to better understanding the migratory movements. However, a correct perception of migratory flows is becoming increasingly difficult due to the increase in clandestine flows and quasi-migrations (such as those of temporary workers from Central-Eastern Europe in the agriculture or services sector). The rise in the number of double residences, both at the internal level (increasing difficulty in distinguishing between main and second residences) and the international level (international executives or pensioners living in two different countries) also intensifies the problem.

Before beginning to analyse the geography of regional migration balances in Europe, it can be useful to recall the major evolutions in migratory movements since the Sixties.

\section{Major trends in migratory movements in Europe since the sixties}

If during the 1960 s the migratory balances in Western Europe were relatively important, this concerned essentially intra-(Western)-European flows (the term "Western-European" being taken here in the broad sense of the word, that is to say the current Europe of Fifteen plus Switzerland and Norway) (Fig. 1 and 2). Their relatively simple geography corresponded mainly to a centre-periphery scheme, as much at the international level (migrations from the poor Mediterranean "peripheral" countries and from Ireland and Finland towards more central countries, especially NorthWestern Europe) as at the national level (rural exodus towards large urban areas, even if the latter were already affected by the beginnings of periurbanisation, though still limited, so that it was generally only slightly perceptible at the NUTS 2 or 3 level.

Figure 1. External migratory balance of the Europe of Fifteen as a whole.

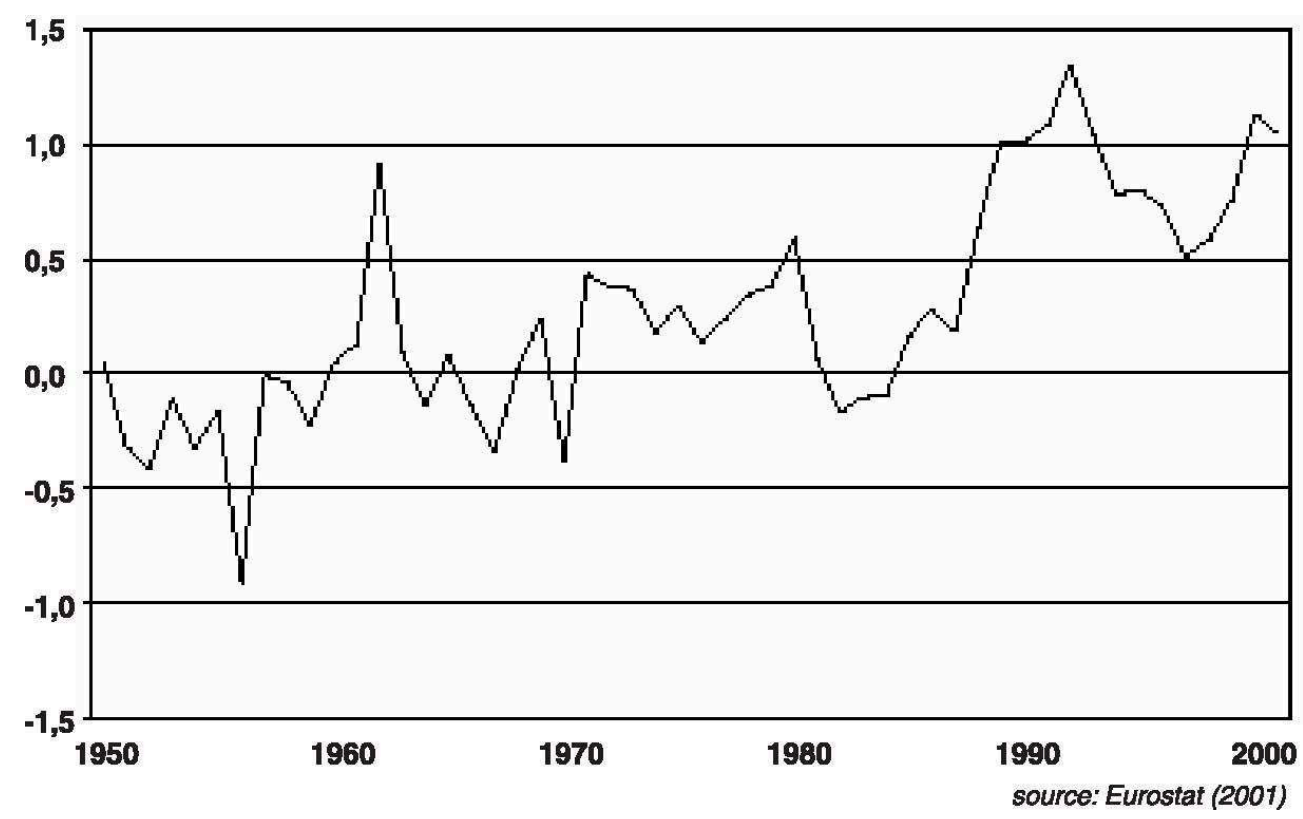


Figure 2. Migratory balances 1960-1970.

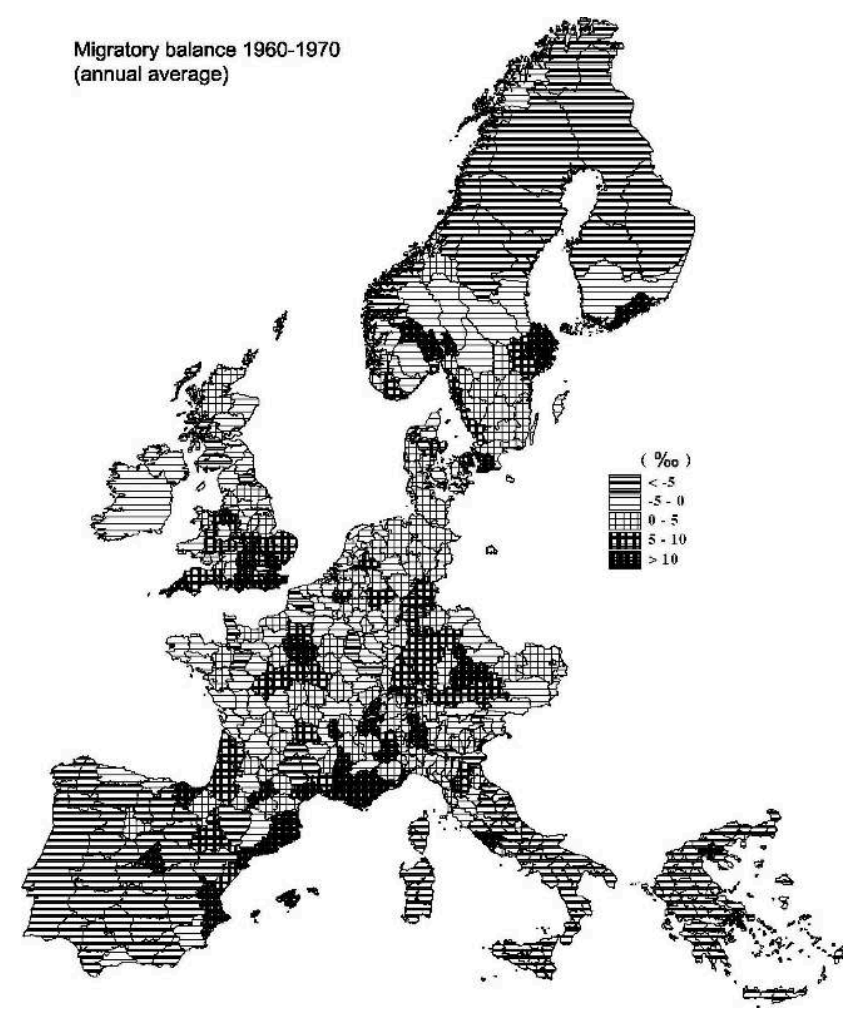

4 The old industrial areas had negative internal migratory movements in spite of a continuing international immigration within the framework of the Fordist industrial developments. These international movements were still often based upon organized recruitment which was extended, from the second half of the 1960s, to recruitment from Yugoslavia, Turkey, North Africa or, in Great Britain, the countries of the New Commonwealth. Globally, on the scale of the Western-European regions, migratory balances were clearly linked to the level of product per inhabitant, from the poor to the affluent regions (see further, Table 3). With regard to the Central-Eastern European countries, they were shut off from the rest of the world, with migratory balances expressing population movements from rural to urban or industrial areas, restricted only to the intra-national level (J.M. Decroly \& al., 1991).

The intra- and international migratory movements slow down considerably in the late 1970 s and during the 1980s. They are no longer linked to the level of development, at least in the European regions considered globally.

In the early 90s (Fig. 3) there is a marked increase in intra- and international flows. With the rest of the world, Western Europe's external migratory balance is, during the course of the decade, the most positive ever recorded in history (Fig. 1). All the Western-European countries, including the Mediterranean countries and Ireland, now show positive balances. Only Portugal remains yet an exception until the mid-Nineties, though quite close to a balance (Table 1). In any case, immigration from abroad remains inferior to the figures recorded in the USA, except between 1988 and 1994, owing to intra-European flows from East to West. External migratory movements at this point bring an essential contribution to the weak demographic growth in Europe, slightly limiting its ageing rate, though the latter does not stop growing (J. Coppel, J.C. Dumont and I. Visco, 2001). However, the essential difference with the 1960s lies in the much 
more individual character of those movements, which result from a "push" effect in the departure countries rather than from a "pull" effect planned by the countries of destination. Another consequence is that the immigrants from outside Europe head for the large metropolitan areas, independently from the potential jobs offered, but where they can find ethnic niches, anonymity and informal jobs: London contains $40 \%$ of the UK's immigrants over the 1996-2000 period; Paris receives $36 \%$ of those heading to France; Lombardy and Latium welcome together $40 \%$ of Italian immigration, etc. This can lead to slower integration in comparison with the previous three or four decades, dominated by organized immigration towards the industrial zones or certain public services and rapidly framed by the structures of the world of work within the large enterprises. Potential frictions are all the more numerous as the native populations of these large cities are themselves increasingly weakened, given the growing social dualisation, at least in the case of those living in neighbourhoods which are financially accessible to the newly immigrated populations.

Table 1. Migratory balances in Western Europe (1960-1999).

\begin{tabular}{|l|c|c|}
\hline & $\begin{array}{c}r \text { correlation ratio between } \\
\text { migratory balances and } \\
\text { GDP/inhab. }\end{array}$ & $\begin{array}{c}r \text { correlation ratio between } \\
\text { migratory balances and } \\
\text { unemployment levels }\end{array}$ \\
\hline Sixties & 0,26 & $\ldots$ \\
Seventies & $-0,17$ & $\ldots$ \\
Eighties & $-0,06$ & $\ldots$ \\
Nineties & 0,11 & $-0,33$ \\
1997-1999 & 0,04 & $-0,31$ \\
\hline
\end{tabular}

Source: C. Vandermotten, G. Van Hamme et al. (2004). 
Figure 3. Migratory balances 1990-1999.

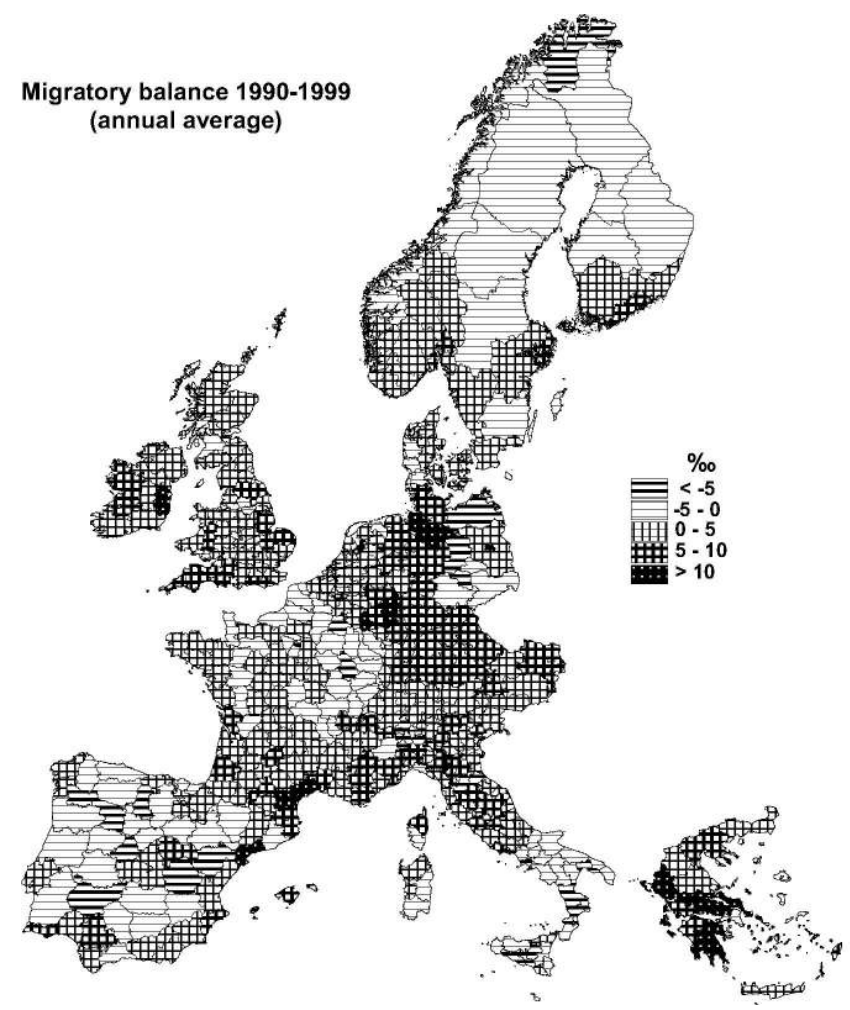

7 As to the Central-Eastern European countries, they are now experiencing less unfavourable international migration flows than could be imagined in view of the strongly negative balances observed in the years that followed the fall of the communist regimes and, globally, weak mobility flows. The Czech Republic and Hungary even record positive balances during the last decade, partly due to their transit position, between the more remote East and Western Europe. They are often used as temporary springboard to the West, though not always, as in the case of the migration flows from Slovakia to Czech Republic. Of course, when interpreting the migratory movements in Central-Eastern Europe, one should also take into account the unrecorded movements, which come close to professional quasi-migrations.

\section{The growing complexity of the causes of migratory movements}

In the countries of Western Europe, the mobility revival on a regional scale in the 1990s results mainly from the sudden opening to the East at the beginning of the decade and from the increase in extra-European immigration. Meanwhile, internal mobility as well as external immigration remain lower than in the USA. International mobility between Western-European countries is much weaker than between the big North-American macroregions.

Each NUTS 2 or 3 level unit making up Western Europe in the broad sense has been attributed to a determined regional economic type depending on the structure of the domestic product, i.e. central metropolitan regions, early industrial regions, other central regions, intermediate regions, Southern peripheral regions, Scandinavian peripheral regions, East Germany, etc. (C. Vandermotten, J.R. Sortia, J. Vanlaer, 1987; C. 
Vandermotten \& P. Marissal, 2000; C. Vandermotten, 2002). The migration trends are all the more directly dependent on the economic structures as the inter-group variance is high. It appears that the inter-group variance accounted for almost half of the total variance during the 1960s (Table 2). The apparent revival of the inter-group logic in the early 1990s is above all due to the fact that Eastern Germany alone constitutes one class of the economic typology.

Table 2. Part of the migratory balances variance of the Western-European regions according to their belonging to an economic type.

\begin{tabular}{|l|c|c|c|c|}
\hline & $\begin{array}{c}\text { Migratory balance } \\
\text { (\%o) } \\
\text { in the 60s }\end{array}$ & $\begin{array}{c}\text { Migratory balance } \\
\text { (\%o) } \\
\text { in the 70s }\end{array}$ & $\begin{array}{c}\text { Migratory balance } \\
\text { (\%o) } \\
\text { in the 80s }\end{array}$ & $\begin{array}{c}\text { Migratory balance } \\
\text { (\%o) } \\
\text { in the 90s }\end{array}$ \\
\hline Austria & 2,1 & 0,0 & 0,3 & 4,3 \\
\hline Belgium & 1,5 & 0,4 & $-0,1$ & 1,4 \\
\hline Denmark & 2,3 & 1,5 & 0,2 & 2,6 \\
\hline Spain & $-1,2$ & 1,7 & $-1,5$ & 1,3 \\
\hline Finland & $-3,6$ & $-0,2$ & 0,7 & 0,2 \\
\hline France & 2,6 & 1,7 & $-0,0$ & 3,8 \\
\hline Greece & $-4,7$ & 3,9 & 1,0 & 5,9 \\
\hline Ireland & $-4,5$ & 4,0 & $-7,4$ & 1,1 \\
\hline Italy & $-1,3$ & 1,2 & 0,7 & 10,2 \\
\hline Luxem bourg & 4,9 & 7,1 & 2,4 & 2,3 \\
\hline Norway & 0,5 & 0,6 & 1,2 & 1,9 \\
\hline The Netherlands & 1,0 & 1,3 & 1,5 & $-0,2$ \\
\hline Portugal & $-13,1$ & 5,9 & 0,4 & 7,9 \\
\hline West Germany & 4,0 & 1,9 & 1,7 & 2,5 \\
\hline Sweden & 3,8 & 0,9 & 1,6 & 3,2 \\
\hline Switzerland & 6,8 & $-3,2$ & 3,1 & 2,0 \\
\hline United Kingdom & $-0,1$ & $-2,2$ & $-0,1$ & \\
\hline
\end{tabular}

SOURCE: C. VANDERMOTTEN, G. VAN HAMME ET AL. (2004).

So, the nature of the movements becomes more complex. Neoclassical theories aiming at explaining the migratory movements by alleged economic rationality, people being supposed to move from the poor to the affluent regions, are no longer at all suitable, if they ever were. There is, for instance, no longer any correlation between migratory balances and regional products by inhabitant (Table 3). The mass exodus from the peripheral areas belongs to the past, except in Scandinavia and in the South of Italy. Large parts of inner peripheral Spain now show positive balances, or at least much less negative than what they used to be in the early 1990s (Fig. 4). Though, this should not be considered a lack of liaison between economy and mobility but rather a differentiation of the nature of such liaisons. Their logics are no more necessarily determined by the labour market. They can also be determined inversely: retirement migrations and heliotropism may lead to new tertiary developments within the environmentally-attractive areas and so attract younger populations as well. Counterurbanisation can partly be explained by property price pressures in the central areas and, in turn, bring about tertiary developments, and so on. 
Table 3. Correlation coefficient between the migratory balances of the Western-European regions (at NUTS 3 or 2 level) and their GDP/inhabitant.

\begin{tabular}{|l|c|c|c|}
\hline & Total variance & $\begin{array}{c}\text { Part of the intra-group } \\
\text { variance }\end{array}$ & $\begin{array}{c}\text { Part of the inter-group } \\
\text { variance }\end{array}$ \\
\hline Sixties & 108,45 & $51,7 \%$ & $48,3 \%$ \\
Seventies & 40,34 & $74,0 \%$ & $26,0 \%$ \\
Eighties & 15,68 & $79,0 \%$ & $21,0 \%$ \\
Nineties & 23,06 & $61,3 \%$ & $38,7 \%$ \\
$1990-92$ & 95,27 & $53,6 \%$ & $46,4 \%$ \\
$1997-99$ & 15,69 & $79,6 \%$ & $20,5 \%$ \\
\hline
\end{tabular}

SOURCE: C. VANDERMOTTEN, G. VAN HAMME ET AL. (2004).

THE COEFfICIENT INCREASES JUST A LITTLE IN THE EARLY 1990S DUE TO THE EXTENSIVE EMIgRATION FLOWS FROM THE FORMER GDR REgIONS, WHOSE GDP/INHABITANT IS PARTICULARLY LOW. THE LAST COLUMN OF THE TABLE SHOWS THE (NEgATIVE) CORRELATION BETWEEN MIgRATORY MOVEMENTS AND UNEMPLOYMENT RATES, BUT IT IS HIGHLY DETERMINED BY THE CONJUNCTION OF HIgH UNEMPLOYMENT RATES AND SIGNIFICANT EMIGRATION FLOWS FROM BOTH AREAS: THE FORMER GDR AND SOUTHERN ITALY.

Figure 4. Migratory balances, 1996-1999.

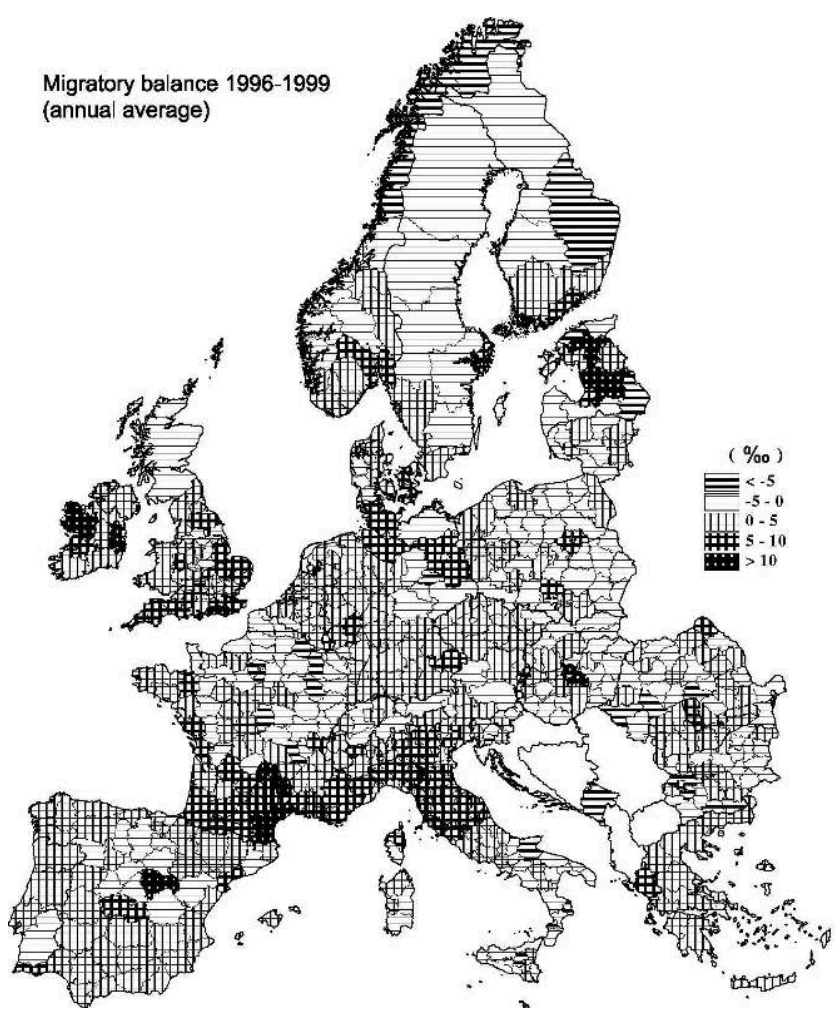

\section{The changing causes of the migratory movements}

11 A variety of causalities are thus replacing the logics proposed by the former neoclassical models.

12 A variance analysis shows that the most significant scale to explain the logic of mobility today is that of the very large intra-national macroregions, which account nowadays for about half of the total variance between Western-European NUTS 2 or 3 regions (whereas the part of variance bound to the differences between countries accounts only for $6 \%$ of the total variance): North to South movements in Scandinavia, Germany, 
Great Britain, and France (here also westward); from East to West in Germany; toward the coasts in Spain; northward in Italy; etc.

Rural exodus is no longer a widespread phenomenon. It becomes increasingly difficult to distinguish between a periurbanisation which occurs ever further away from the metropolises, and a more autonomous counter-urbanisation. Yet in France, where most of the rural départements no longer show negative balances, analyses at a finer level show that it is essentially the central parts of those rural départements of the West and South, situated on the periphery of the prefectures or the largest cities, that gain population, while their fringes often continue to lose inhabitants.

In spite of the continuation of a remote and diffuse periurbanisation, most of the metropolitan areas now show positive balances, even in their central districts, with the notable exception of the Ile-de-France. This is not so much due to the effects of gentrification, which remains quite insufficient, from the point of view of a global demographic effect, to make up for the impact of periurbanisation and counterurbanisation, as to the preferential choice of the metropolitan areas by international immigration. This is what explains the Parisian exception: the international appeal of France is weak compared to that of Great Britain, for instance. The metropolitan areas of West Germany benefit at the same time from immigration from Central-Eastern Europe and from the Eastern part of Germany.

In the countries of Central-Eastern Europe, the last decade is characterized by a double trend, which expresses patterns quite behind or different from the West.

On the one hand, there are two attractive types of areas:

- The capital regions, just as during the communist period, but the phenomenon is now accompanied by a periurbanisation that was almost nonexistent before;

- Some regions, among the most Western ones, near the old EU borders and benefiting from industrial transfers.

On the other hand, three types of regions tend to show negative balances:

- The old and the heavy industry areas, for a long time the beneficiaries of socialist planning (but all of which no longer showed positive balances as soon as the 1980s);

- The Eastern areas;

- The areas with a marked rural character (except in Romania), especially those of nonsocialised agriculture of Eastern and South-Eastern Poland.

\section{A typology of the migratory balances of the European regions based on their age structures}

Some major trends underlie the factors that will allow us to produce a typology of the European regions from the point of view of their migratory balances. Putting these trends in evidence becomes clearer when examining the balances by age, which show the categories of people who are attracted or leaving. It allows bettering understanding the multiple contradictory movements of the Nineties.

These trends are as follows:

- In Western Europe, internal migratory movements expressing the main macrogeographical trends we have described; 
- Still in Western Europe, external migrations benefiting mainly the metropolitan areas and whose extent determines, in most European metropolises, a recent revival of the population growth, except, as we have seen, in the Paris area;

- As regards balances by age class, an "escalator effect", according to the British geographer Tony Fielding; in other words a special appeal of the metropolitan areas - especially their central parts - to people aged between 20 and 29, attending to the University or at the beginning of their professional career (Fig. 5);

- The continuation of the periurbanisation movements, extending further and further from the big cities, particularly among the 30-44 year-olds (and their young children) (Fig.6);

-A reinforcement of the "heliotropic" trend or the appeal of more attractive areas to the 50+ age-group, but sometimes also to households with children, especially in places where environmental and tourist-based revivals provide new economic activities and combine with economic wealth. The effect of return migrations can also be observed in Ireland or Portugal, or, to a lesser extent, in the South of Italy;

- In Central-Eastern Europe, weak internal mobility, to which the spatial trends described above belong (and, as we have seen, a quite rapid weakening of the negative balances toward the West, immediately after the very first post-communist years, subject to the unregistered temporary migrations).

Figure 5. Migratory balances of the population between 20 and 29, 1996-2000.

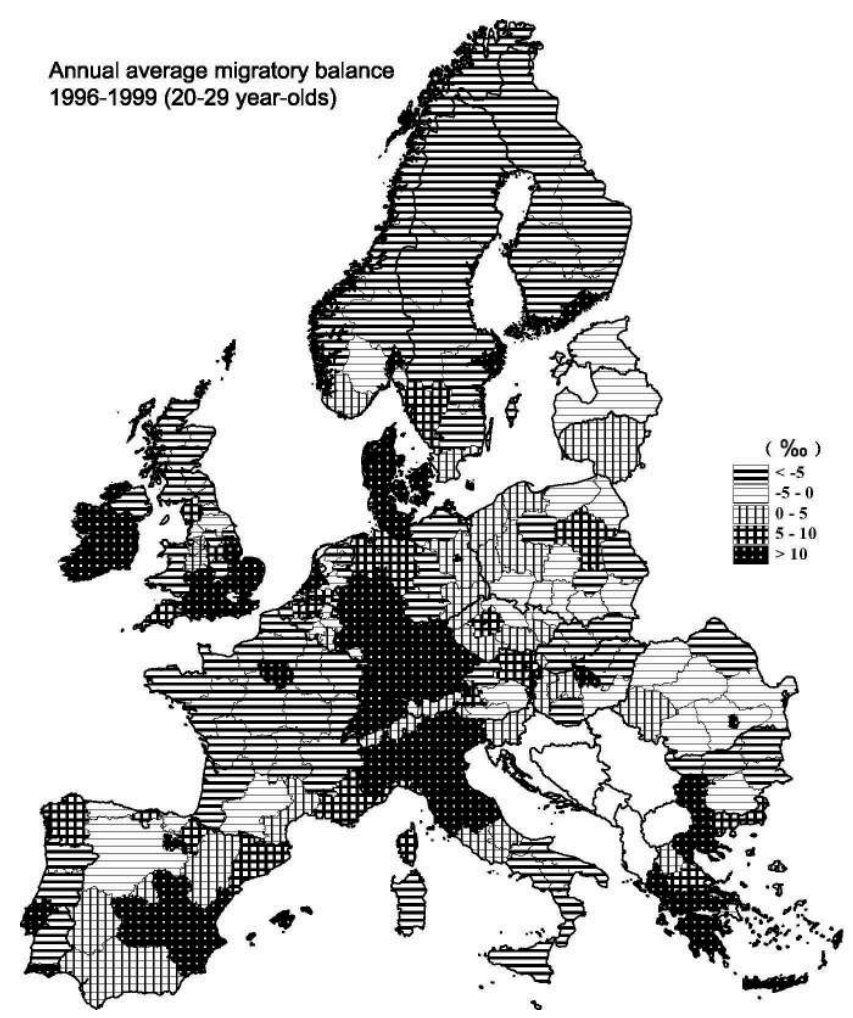


Figure 6. Migratory balances of the population between 30 and 44, 1996-2000.
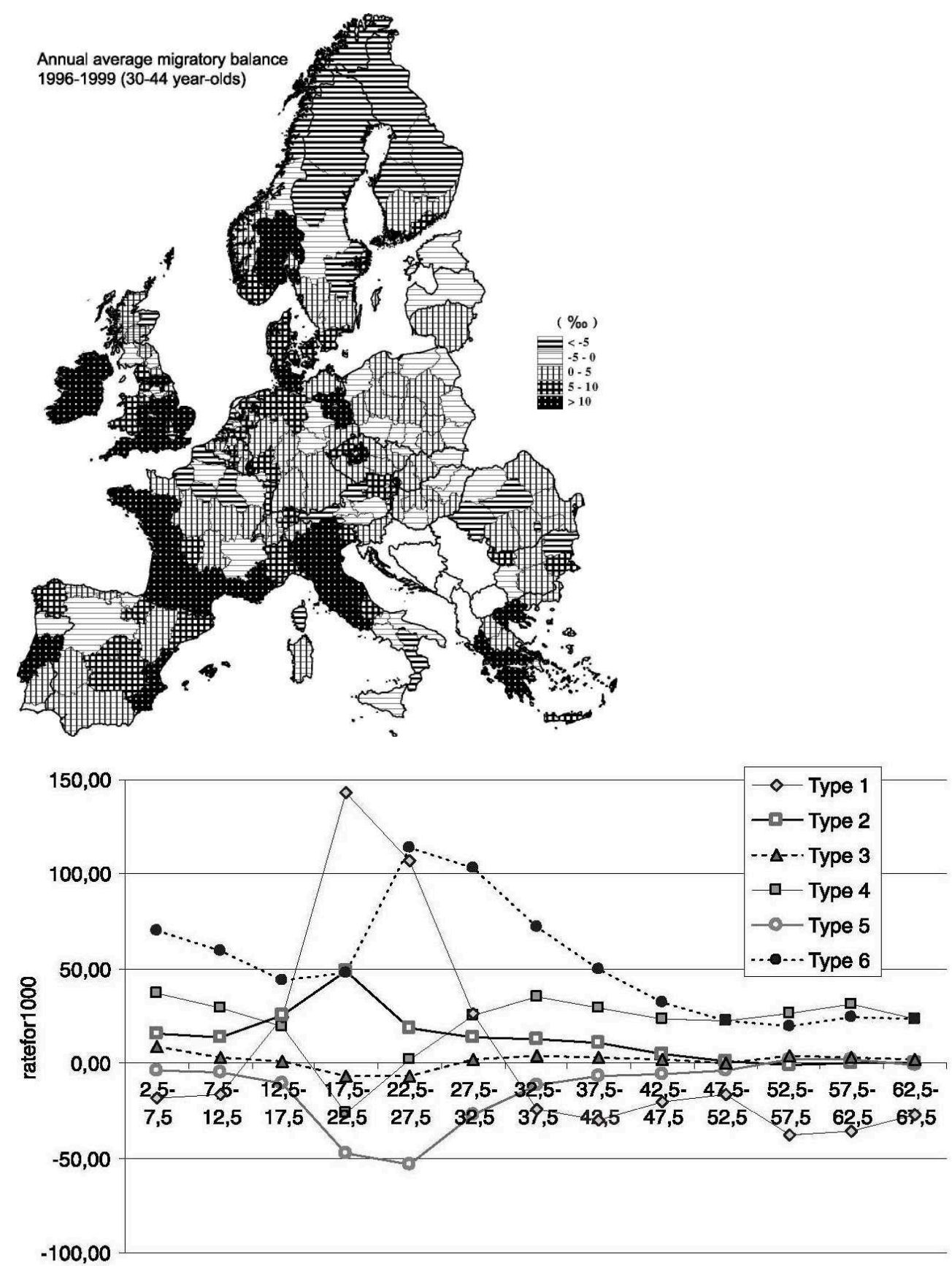

ageclasses 
Figure 7. Cluster typology of migratory balances by age groups, 1995-2000.

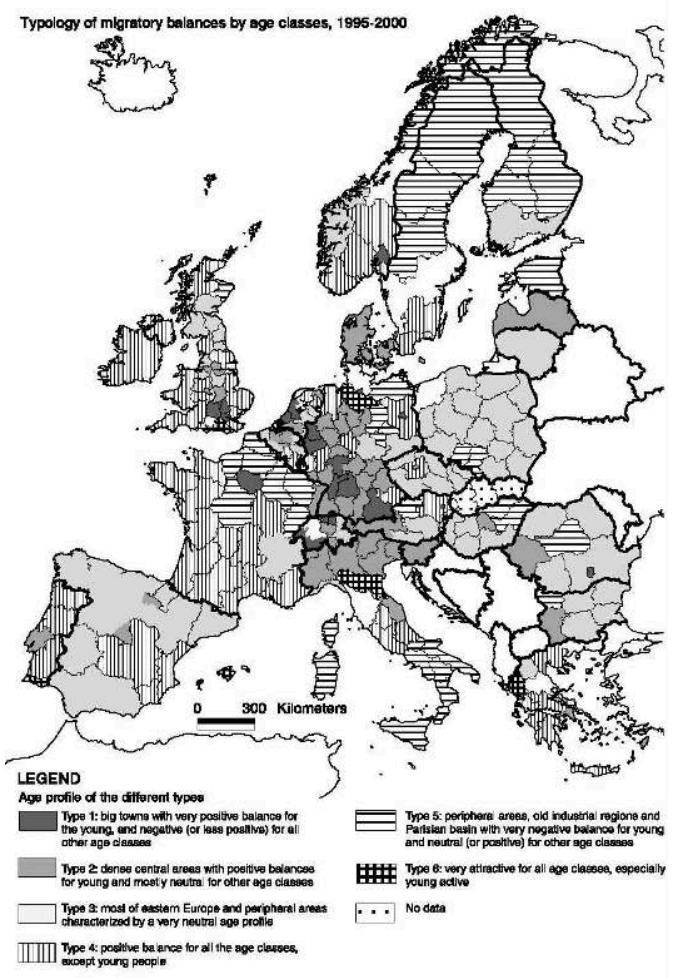

The crossing of migratory trends by major age groups allows us to build a cluster typology in 6 classes, as shown in Figure 7, for the 1995-2000 period ${ }^{2}$. This typology enables us to distinguish:

- Metropolitan areas characterized by a strong mobility, a distinct immigration of young adults and a clear emigration at all other ages (type 1). In function of the volume of foreign immigration, these areas are faced today with a new population growth (London, BrusselsCapital) or, on the contrary, a population decrease (Ile-de-France);

- Type 2 represents a milder version, concerning often central densely populated and urbanized regions, mainly present in Western and Southern Germany and in Northern Italy: less appealing to young adults but also less repellent, not to say slightly attractive for the other age classes;

- Inversely, areas characterized by an emigration of young adults and immigration at all other ages (type 4). It concerns either newly economically attractive (and eventually tourist) but however semi-peripheral regions (Southern and Western France, South-East of Belgium, Cornwall and Wales, Ireland, Northern Scotland, South-East of Sweden, etc.) or outer fringes of perimetropolitan areas (around Oslo, Berlin, Prague, Vienna, London, Madrid, etc.);

- Quite few regions appealing to all age classes, but mainly to households with children (the 30-44 year-olds and their children) (type 6). These situations seem to correspond to different causes: residential and economically dynamic parts of perimetropolitan South-East of England or around Hamburg, urbanized and dynamic Emilia-Romagna, tourist Algarve, Epire, appealing for Albanian immigration ;

- On the opposite end of the scale, relatively stable areas at all ages but young adults, for which they are strongly repellent (type 5). These areas are left at an early age and are seldom if not never returned to : this is the case of several areas of early industrialisation, like Nord-Pas-de-Calais and Lorraine in France, Saxe-Anhalt in Eastern Germany, Upper Silesian Basin in Poland, etc., of the Parisian basin outside Ile-de-France and of some 
peripheral regions keeping yet the negative dynamics of the Sixties (Southern Italy), or even reinforcing it (Northern Scandinavia);

- Finally, vast areas, scarcely mobile at all ages, such as large parts of Central-Eastern Europe and Spain, or Hainault, Liege, West Flanders and Limburg in Belgium (type 3).

\section{Synthesis of the main migratory flows since the Sixties}

21 Table 4 summarises the main trends in migratory movements since the 1960 s and their evolving causes.

Table 4. A synthesis of the migratory movements since the $1960 \mathrm{~s}$.

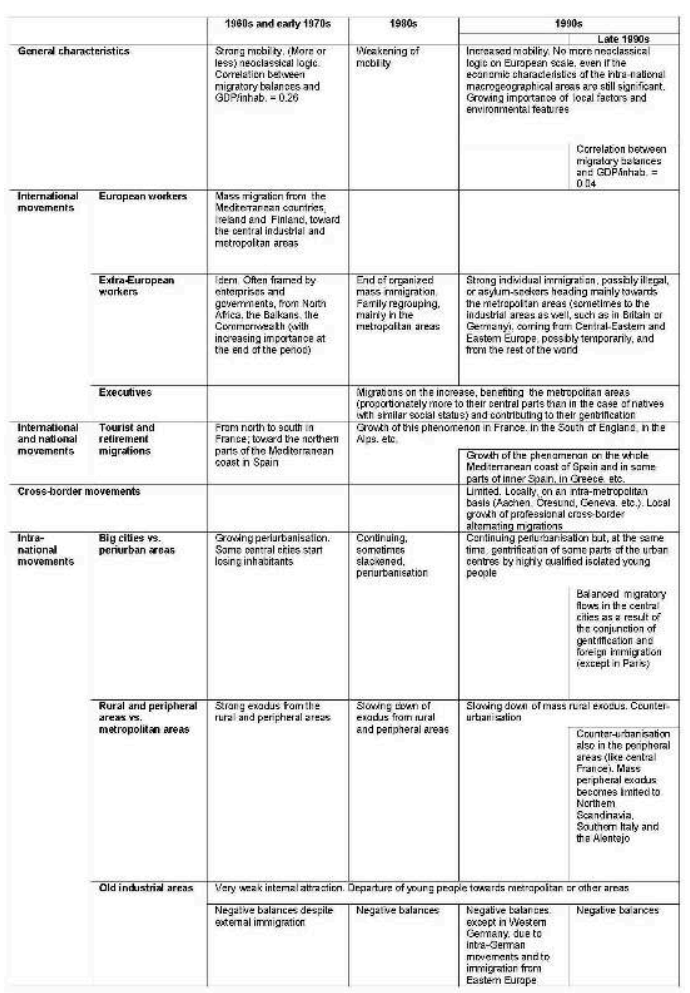

\section{Conclusions}

Beyond the problems linked to the spatial scale of the analysis, which can hide shortdistance mobility flows or cause diverse impressions of periurbanisation movements according to differences in the set-up of the statistical entities, and beyond the growing difficulties in the study of residential mobility, observing migratory movements in Europe over the last ten years calls into question certain idées reçues. There is no "invasion" of Europe by an extra-European immigration or, in Western Europe, from Central-Eastern or Eastern Europe. These types of flows are in any case insufficient to counter the growing ageing of the European population. Extra-European flows remain largely inferior to those heading to the USA from the rest of the world. The flows between Central-Eastern Europe and Western Europe have largely dried up after the first years that followed the fall of the communist regimes. On the contrary, the 
populations from Central-Eastern Europe seem today relatively immobile, subject to a better knowledge of the temporary flows. As regards Southern Europe and Ireland, traditional emigration trends belong to the past. The intra-national logics are still dominant when explaining migratory movements and, except for periurbanisation, they are dominated by behaviours that have to be examined at a macroregional level. A growing part of migratory movements is no longer linked, at least in a direct and allegedly rational way, to the state of the labour market. An important last conclusion concerns rural exodus, which has decreased a fair amount, when it has not totally disappeared, in large parts of Europe. It only has a significant impact on the ultraperipheral areas, mainly in Scandinavia, where emigration has even strengthened with regard to the previous decades.

\section{BIBLIOGRAPHY}

CHAMPION T., MÖNNESLAND J. \& VANDERMOTTEN C. (1996), “The new regional map of Europe”, Progress in Planning, 46, 1, pp. 1-89.

COPPEL J., DUMONT J.C. \& VISCO I. (2001), Trends in Immigration and Economic Consequences, OECD, Economics Department, ECO/WKP (2001)10.

DECROLY J.M., VANLAER J. \& al. (1991), Atlas de la population européenne, Bruxelles, Editions de l'Université de Bruxelles.

KING R. (ed.) (1993), Mass Migrations in Europe, The Legacy and the Future, London, Belhaven Press. SOPEMI (2001), Tendances des migrations internationales, Rapport annuel.

VANDERMOTTEN C. (2002), “Les disparités spatiales en Europe et leurs évolutions: 1960-2000”, Cahiers Économiques de Bruxelles, 45, 4, pp. 23-58.

VANDERMOTTEN C. \& MARISSAL P. (2000), “Une nouvelle typologie économique des régions européennes”, L'Espace géographique, pp. 289-300.

VANDERMOTTEN C., SORTIA J.R. \& VANLAER J. (1987), Atlas économique de l'Europe, Bruxelles, Société Royale Belge de Géographie et Université Libre de Bruxelles.

VANDERMOTTEN C., VAN HAMME G., MEDINA LOCKHART P., WAYENS B. \& al. (2004), Migrations in Europe: the four last decades, Rome, IGU-Home of Geography Publications, vol. V.

\section{NOTES}

1. Except for the typologies presented at the end of this article, the levels taken into consideration were as follows: the French departments, the Belgian, Dutch, Italian, Spanish provinces, the British counties, etc. (i.e. NUTS 2 or 3 depending on the country). In Germany and Austria, NUTS 3 level corresponds to that of the too numerous "Kreise", and we have considered the "Regierungsbezirke" or the "Länder" (NUTS 2 level) respectively. The aim of combining these two EUROSTAT levels is to create as homogenous a geographical division as possible, all the while 
aware that the type of scale used can highlight or, inversely, hide movements of different natures, from fine scale periurbanisation to coarse scale intranational or even international flows.

2. Research is still underway to check some data. However, the possible corrections should not undermine the major trends. At this stage of data collection and processing, the principal uncertainties concern data relating to migratory trends of the elderly in Slovakia, Austria and Switzerland.

\section{ABSTRACTS}

Migratory movements, as well intra- as international, increased in Europe during the Nineties, after a slowing-down between the mid-Seventies and the end of the Eighties. The collapse of the Iron Curtain is only one reason among others explaining those growing migratory movements at the beginning of the Nineties. The geographical pattern of the migratory balances which emerged during the Nineties is much more complex than the Fordist one prevailing during the Sixties and the beginning of the Seventies. The migratory balances by age allows us to better understand the various new causes of the migratory patterns.

Les mouvements migratoires, tant intra- qu'internationaux, ont augmenté en Europe durant les années quatre-vingt-dix, après un ralentissement depuis le milieu des années soixante-dix jusqu'à la fin des années quatre-vingt. L'ouverture de l'Europe centre-orientale et orientale est loin d'être la seule raison expliquant la forte reprise des mouvements de population au début des années quatre-vingt-dix. La géographie des mouvements migratoires actuels dessine un patron spatial bien plus complexe que celui qui prévalait durant les années soixante et le début des années soixante-dix et qui était caractérisé avant tout par une logique fordiste de migrations de travail des périphéries vers les centres. L'examen des bilans migratoires par âge permet de mieux saisir les nombreuses motivations nouvelles qui sous-tendent la reprise migratoire des années quatre-vingt-dix.

\section{INDEX}

Mots-clés: Europe, mouvements migratoires, mobilité, structures par âge

Keywords: Europe, migrations, mobility, age structures

\section{AUTHORS}

\section{CHRISTIAN VANDERMOTTEN}

Université Libre de Bruxelles, cvdmotte@ulb.ac.be

\section{GILLES VAN HAMME}

Université Libre de Bruxelles, gvhamme@ulb.ac.be 


\section{PABLO MEDINA LOCKHART}

Université Libre de Bruxelles, pmedinal@ulb.ac.be 